\title{
PRODUCTIVITY AND QUALITY OF SUGAR BEET AS INFLUENCED BY NITROGEN FERTILIZER AND SOME MICRONUTRIENTS
}

\author{
MOUSTAFA, ZEINAB R., AMAL M. K. SOUDI AND KHALIL EL-SHENAWY M.
}

Physoil.\& Chemi. Res. Sec., Sugar Crops Res. Inst., ARC, Giza, Egypt.

(Manuscript received 6 December 2010)

\begin{abstract}
Two field experiments were conducted during 2008/2009 and 2009/2010 seasons at Sakha Research Station, Kafr EL-Shaikh Governorate to study the influence of three nitrogen rates $(75,100$ and $125 \%)$ of recommended rate $(R R=80 \mathrm{Kg} \mathrm{N} / \mathrm{fed})$, sprayed with $\mathrm{Zn}, \mathrm{Mn}$ and $\mathrm{Fe}$ individually or in mixture, on some chemical composition, juice quality and yield of sugar beet plants.

Decreasing $\mathrm{N}$ dressing up to $60 \mathrm{Kg} \mathrm{N} / \mathrm{fed}$ ( $75 \%$ of RR) significantly decreased photosynthetic pigments (chlorophyll a, b and carotenoids) at the age of 120 days from sowing in the two seasons, also a reduction in sucrose $\%$ and some technological parameters such as sugar extractable (SEX), sugar losses to molasses (SLM) and sugar coefficient (SCO), yield component (root length, diameter and fresh weight of tops in the two seasons have been recorded. Yields of roots and sugar, uptake of $\mathrm{N}, \mathrm{Mn}$ and $\mathrm{Zn}$ had the same trend. On the other hand, increasing $N$ dressing up to $100 \mathrm{Kg} \mathrm{N} /$ fed (125\% of RR) significantly increased photosynthetic pigments i.e. chlorophyll $\mathrm{a}, \mathrm{b}$ and carotenoids at the age 120 days from sowing in the two seasons, $\mathrm{Na}, \mathrm{K}$ and $\mathrm{a}-$ amino $\mathrm{N}$ as impurities, sugar loss to molasses (SLM), yields of roots and sugar but juice purity was significantly decreased.

Foliar spray with $\mathrm{Mn}, \mathrm{Zn}$ and $\mathrm{Fe}$ individually or in mixture significantly increased chlorophyll $\mathrm{a}, \mathrm{b}$ and carotenoids in both samples in the two seasons. Sucrose $\%$ and impurities as $\mathrm{K}$ and aamino $\mathrm{N}$ were significantly increased but juice purity was significantly decreased. Root length, diameter, fresh weight of roots and tops, sugar yield were significantly affected. Foliar spray with $\mathrm{Zn}, \mathrm{Mn}$ and $\mathrm{Fe}$ significantly increased their uptake and $\mathrm{N}$ uptake. Foliar spray with the mixture of $\mathrm{Zn}, \mathrm{Mn}$ and Fe exhibited the best treatment, where it gave the highest values of most traits under study.

The interaction between $\mathrm{N}$ at the high rate and the mixture of $\mathrm{Zn}, \mathrm{Mn}$ and $\mathrm{Fe}$ was the superior treatment where, it gave the highest values for chl a, b and carotenoids, $\mathrm{K}$, $\mathrm{a}$ - amino $\mathrm{N}$, juice purity and $\mathrm{N}$ uptake.
\end{abstract}

Keywords: Nitrogen, $\mathrm{Zn}, \mathrm{Mn}$ and Fe, sugar beet.

\section{INTRODUCTION}

Sugar beet is one of just two crops (the other being sugar cane) which constitute the only important sources of sucrose. In Egypt, sugar production is still insufficient to cover consumption therefore, many devoted attempts to improve beet 
quality and quantity. These may be achieved via nutrition which had a great effect on beet productivity. Nitrogen management is one of the important keys to accomplish this goal. A sufficient nitrogen supply of sugar beet is decisive to a considerable extent both for root yield and its quality. Over supply as well as undersupply of nutrients, in particular of nitrogen, means a reduction of quality of the harvested product (Jozefyova et al, 2004). Nitrogen fertilization promotes vigorous early season growth thereby reducing the number of days to canopy closure. Early closure allows the sugar beet to make better use of sunlight and more sugar is produced. In this connection, nitrogen is the sensitive elements that affect the beet production and sugar content (Zhou, 1993). Franzen (2003) found that excess nitrogen reduced root sucrose content and higher impurity level as well as poor recoverable sugar yield. (Cai, and Ge 2004) stated that the nitrogen content of sugar beet plant was significantly and positive correlated with nitrogen amount used and found that the study of nitrogen amount on beet production and sugar content will be important and significant

Micronutrients as foliar application are particularly useful under Egyptian soil conditions where, it suffers greatly from alkalinity, therefore, most micronutrients fixed and become unavailable to plant uptake (Shalaby, 1998).

Micronutrients deficiency is one of many factors that affect sugar beet production. This deficiency is particularly refered to many factors such as the intensive cropping system in Egyptian agriculture and the reduction in the amount of Nile alluvium after the construction of Aswan High Dam as will (Shalaby, 1998). Application of foliar Fe combined with $\mathrm{Zn}$ and $\mathrm{Mn}$ was very effective in increasing root and sugar yields as well as juice purity and sugar content, which in turn improve sugar extractability (Moustafa et al., 2006). Great attention to the response of sugar beet to micronutrients has been recorded by many workers (Moustafa et al., 2006 and Soudi and El-Guibali, 2008).

The aim of this work is to evaluate the effect of nitrogen rates and some micronutrients on growth, quality and quantity of sugar beet.

\section{MATERIALS AND METHODS}

Two field trials were set up in Sakha Research Station (ARC) at Kafr EL-Shaikh Governorate to study the effect of three rates of nitrogen (60, 80 and $100 \mathrm{~kg} \mathrm{~N} / \mathrm{fed}$ ) along with foliar spray with five treatments control (without micronutrients), $\mathrm{Zn}, \mathrm{Mn}$, Fe and mixture of $\mathrm{Zn}+\mathrm{Mn}+\mathrm{Fe}$ and their interactions on growth, root quality and yield 
of sugar beet plants. Average mechanical and chemical properties of the experimental soil are illustrated in Table (1).

Table 1. Soil mechanical and chemical properties of the experimental site in the two seasons.

\begin{tabular}{|c|c|c|c|c|c|c|c|c|c|c|c|c|c|c|c|}
\hline \multicolumn{10}{|c|}{ Soil properties } & \multicolumn{6}{|c|}{ Available nutrients (ppm) } \\
\hline Seasons & $\begin{array}{c}\text { Coarse } \\
\text { sand } \\
\%\end{array}$ & $\begin{array}{c}\text { Fine } \\
\text { sand } \\
\%\end{array}$ & $\begin{array}{c}\text { Silt } \\
\%\end{array}$ & $\begin{array}{c}\text { Clay } \\
\%\end{array}$ & 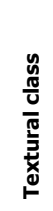 & $\begin{array}{l}\stackrel{0}{\circ} \\
\text { ర్ల } \\
\text { తు }\end{array}$ & 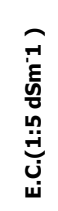 & pH & 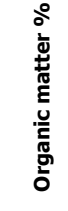 & $\mathbf{N}$ & $\mathbf{P}_{2} \mathbf{O}_{5}$ & K & $\mathrm{Fe}$ & $\mathrm{Zn}$ & Mn \\
\hline 2008/09 & 5.05 & 16.5 & 30.1 & 47.0 & \multirow{2}{*}{$\begin{array}{l}\text { Silty } \\
\text { clay }\end{array}$} & 3.45 & 2.74 & 7.95 & 1.85 & 30.2 & 9.01 & 419 & 9.51 & 8.61 & 13.4 \\
\hline $2009 / 10$ & 4.73 & 15.1 & 28.0 & 49.3 & & 2.60 & 3.35 & 8.13 & 1.89 & 31.1 & 9.63 & 398 & 12.6 & 7.81 & 14.5 \\
\hline
\end{tabular}

A multigerm sugar beet variety kawemira was planted on $25^{\text {th }}$ and $27^{\text {th }}$ of October 2008 and 2009 seasons respectively. The experimental design was split plot with three replications where, the three nitrogen rates 75,100 and $125 \%$ of the recommended rate ( $80 \mathrm{~kg} \mathrm{~N} / \mathrm{fed}$ ) were allocated in the main plots which was assigned into five sub plots including control (without micronutrients), $2.5 \mathrm{~g} \mathrm{Zn} / \mathrm{L}$ as zinc sulfate (40\% Zn), $2.5 \mathrm{~g} \mathrm{Mn/L}$ as manganese sulfate (36\% Mn) and $1.5 \mathrm{Fe} / \mathrm{L}$ as Fe-EDTA (13.2 $\% \mathrm{Fe}$ ) and the mixture of $\mathrm{Zn}, \mathrm{Mn}$ and $\mathrm{Fe}$ in $400 \mathrm{~L}$ water / fed. Nitrogen fertilizer was added as urea form $(46 \% \mathrm{~N})$ in two equal doses the first after thinning and the second after 30 days later. Foliar spraying with micronutrients was applied after 70 and 90 days from sowing. The sub plot size was $21 \mathrm{~m}^{2}$ (1/200 fed). All cultural practices for growing sugar beet were done as recommended.

Random samples of leaves were taken from each plot after 85 and 105 days from sowing to determine photosynthetic pigments i.e. chlorophyll $a, b$ and carotenoids (mg/g fresh weight) according to the method of Wettstein (1957).

On the other hand, samples were taken at harvest (after 210 days from sowing) to determine:

\section{Root quality in the second season}

- Sucrose (pol \%), purity\% and impurities ( $k$, Na and a- amino N (meq/100g beet).

All traits were determined using automatic French system (Hycel)

-Some technological parameters: [sugar lost to molasses (SLM), sugar extractable (SEx) and alkalinity coefficient (AC) were calculated using an automatic French system (Hycel).

-Root and sugar yields (ton/fed).

\section{Root elemental uptake in two seasons}

- $\mathrm{N}$ as macro elements.

- Zn, Mn, and Fe as microelements

All elements were determined according to A.O.A.C. (1990) 


\section{Yield components in two seasons}

- Average root length and root diameter/plant (cm).

- Average fresh weight of roots and tops/ plant $(\mathrm{Kg})$.

Analysis of variance was computed for each trait in each season according to Steel \& Torrie (1980). Least significant differences (LSD) at 5\% level of probability were used to compare treatment means.

\section{RESULTS AND DISCUSSION}

\section{Photosynthetic pigments}

\section{Effect of $\mathbf{N}$ fertilizer rates}

Results of photosynthetic pigments i.e. chlorophyll $\mathrm{a}, \mathrm{b}$ and carotenoids in 2008/09 (I) and 2009/10 (II) seasons are listed in Table (2). Data showed that decreasing $\mathrm{N}$ rate to $75 \%$ of $\mathrm{RR}$ significantly decreased chlorophyll $\mathrm{a}, \mathrm{b}$ and carotenoids in the samples at 90 and 120 days from sowing in both seasons except chlorophyll a and carotenoids in the first season in sample at 90 days from sowing. On the other hand, increasing the rate of $\mathrm{N}$ to $125 \%$ of RR increased chlorophyll $\mathrm{a}, \mathrm{b}$ and carotenoids in the two samples in both seasons. The increases were significant in the second sample at the age of 120 days in both seasons. This increase may be due to the positive effect of $\mathrm{N}$ fertilization on the vegetative growth of sugar beet plants and consequently increasing the photosynthetic area capable for solar energy conversion. Similar results were obtained by Moustafa and Omran (2006).

\section{Effect of micronutrients}

Foliar spray with $\mathrm{Zn}, \mathrm{Mn}$ and $\mathrm{Fe}$ individually or in mixture significantly increased chlorophyll a, b and carotenoids in both samples in the two seasons as compared with control (without micronutrients).The mixture of micronutrients together was the best treatment where, it gave the highest value of chlorophyll $a, b$ and carotenoids in both seasons in two samples ages. The positive effect of micronutrients may be due to its role as activator or coenzymes in all vital biosynthetic processes in plant such as chlorophyll synthesis. The same trend was obtained by Soudi and El-Guibali (2008) who found that Fe with $\mathrm{Zn}$ tended to show significantly an increase in photosynthetic pigments.

\section{Effect of the interactions}

Data in Table (2) showed that there was a significant difference among all interactions order on chlorophyll $\mathrm{a}, \mathrm{b}$ and carotenoids in both samples except chlorophyll $a$ in the first sample in both seasons and chlorophyll $b$ in the second sample in the first season. In general, the interaction between $\mathrm{N}$ fertilizer at the high rate and the mixture of $\mathrm{Zn}, \mathrm{Mn}$ and Fe was the superior treatment, where, it exhibited the highest chlorophyll $a, b$ and carotenoids values. 


\section{Table 2}




\section{Root quality and some technological parameters Effect of $\mathbf{N}$ fertilizer rates}

Root quality comprises several parameters i.e. sugar content, impurities or non sugar (such as potassium, sodium and a-amino $\mathrm{N}$ ) and juice purity. Results in the second seasons are presented in Table (3) and indicated that, $\mathrm{N}$ dressing at the rate $60 \mathrm{~kg} \mathrm{~N} /$ fed (75\% of RR) decreased all the root quality traits i.e. sucrose \%, impurities ( $\mathrm{Na}, \mathrm{K}$ and a- amino $\mathrm{N}$ ) and juice purity \% as compared with RR. It is worth to mention that the reduction was significant for sucrose \% only. Data also cleared that excess nitrogen (125\% of RR) increased root sucrose $\%$ but statistically was not significant. While, all impurities traits were significantly increased. On the other hand, juice purity was significantly decreased. From above mentioned results, it is important to note that underrate or overrate significantly decreased most root qualities. In this connection, Milford and Watson (1971) showed that excess nitrogen fertilizer increased the fraction of the assimilate entering the root that was used in growth at the expense of that stored as sugar. Thus, plants with more nitrogen had a smaller proportion of their root dry weight as sugar because more was used in growth. The reduction in purity \% was defected from exceed $\mathrm{N}$ dose over rate may be due to the increase in non sugar contents such as a-amino $\mathrm{N}$ which affected sugar accumulation in roots and hence sugar extraction. The above results are partially in agreement with those recorded by Jozefyova et al, (2004) who found adjust $\mathrm{N}$ doses resulted in better quality due to decreasing amino- $\mathrm{N}$ concentration of sugar beet by about $30 \%$ and less residual nitrate after harvest. Oversupply as well as undersupply of soil nutrients, in particular of nitrogen, means a reduction of quality of the harvested product.

Dealing with the effect of the two $\mathrm{N}$ fertilizer levels (60 and $100 \mathrm{Kg} \mathrm{N} / \mathrm{fed}$ ) on some technological parameters i.e sugar loss to molasses (SLM), sugar extractable (SEX) and sugar coefficient (SCo) at harvest time as compared with RR (80 kg N /fed). Data in Table (3) showed a significant decrease in SLM, SEx and SCo as N application at $75 \%$ of RR. While, overrate of N (125\% of RR) led to significant increase SLM only. Such effect may be due to that excess $\mathrm{N}$ significantly increased all impurities as mentioned especially a-amino $\mathrm{N}$, which necessarily had to be taken into account in almost all calculations aimed at assessing the contribution of the nonsugar to potential loss of sugars into molasses (Van Geijn et al, 1983). 


\section{Table 3}




\section{Effect of micronutrients}

Data in Table (3) illustrated that in general, foliar spray with $\mathrm{Zn}, \mathrm{Mn}$ and $\mathrm{Fe}$ individually or in mixture significantly increased sucrose \%, impurities as $\mathrm{K}$ and aamino $\mathrm{N}$ but significantly decreased $\mathrm{Na}$ as compared with control (without micronutrients). These results led to significant decrease in juice purity under $\mathrm{Mn}, \mathrm{Fe}$ and the mixture of $\mathrm{Zn}+\mathrm{Mn}+\mathrm{Fe}$. It is worth to mention that beet sprayed with the mixture of $\mathrm{Zn}, \mathrm{Fe}$ and $\mathrm{Mn}$ gave the highest percent of sucrose and the lowest percent of purity. Such effect may be due to that the increase in impurities was much higher than the increase in sucrose $\%$.

As for the effect of micronutrients on some technological parameters, the available data in Table (3) showed significant increase in SLM and SEx as compared with control (without micronutrients). From results, it is mentioned that in spite of micro-nutrients particularly, the mixture of $\mathrm{Zn}, \mathrm{Mn}$ and $\mathrm{Fe}$ increased sugar loss to molasses, the extractable sugar increase may be due to the highest increase of sucrose\%. These results coincide with those reported by Moustafa et al, (2006), Moustafa and Omran (2006) who stated that treating sugar beet plants with trace elements have a considerable influence on the metabolic activities and in turn exert an increase in its sugar content.

\section{Effect of the interactions}

The interactions between $\mathrm{N}$ rates and some micronutrients $\mathrm{Mn}$, Fe individually or the mixture of $\mathrm{Zn}+\mathrm{Mn}+\mathrm{Fe}$ significantly affected $\mathrm{K}$, a amino $\mathrm{N}$ and purity. Meantime the highest purity was obtained when beet treated with $N$ at $125 \%$ of RR and foliar spray with Zn. Data also cleared that all interactions significantly affected both SLM, SEx or SCo.

\section{Root and sugar yield}

\section{Effect of $\mathbf{N}$ fertilizer rates}

Data in Table (3) revealed that decreasing the rate of $\mathrm{N}$ to $75 \%$ of $\mathrm{RR}$ significantly decreased roots and sugar yield. On the contrary, increasing $\mathrm{N}$ rate to $125 \%$ of RR significantly increased roots and sugar yield.

\section{Effect of micronutrients}

Treatment with $\mathrm{Zn}, \mathrm{Mn}$ or Fe individually caused increase in root yield but this increase was not significant (Table, 3 ). Whereas, the mixture of them led to significant increase in roots yield. As for, sugar yield, it was significantly increased due to foliar sprays with $\mathrm{Zn}, \mathrm{Mn}$ and $\mathrm{Fe}$ individually or in mixture. The present results are in harmony with those of Moustafa et al, (2006) who found that $\mathrm{Fe}, \mathrm{Zn}$ and $\mathrm{Mn}$ significantly increased roots and sugar yields. 


\section{Effect of the interactions}

The interactions between $\mathrm{N}$ fertilizer rate and micronutrients did not show any significant increase for roots or sugar yield.

\section{Yield component}

\section{Effect of $\mathbf{N}$ fertilizer rates}

Root length and root diameter as well as root and top fresh weights as affected by three rates of nitrogen are presented in Table (4).

Results cleared that growth traits mentioned above significantly decreased by decreasing the rate of $\mathrm{N}$ fertilizer from 100 to $75 \%$ of RR at harvest in both seasons except for fresh weight of root. On the other hand, the high $\mathrm{N}$ fertilizer ( $125 \%$ of RR) increased all growth traits in both seasons as compared with RR at $80 \mathrm{Kg} \mathrm{N} / \mathrm{fed}$. The stimulatory effect of $\mathrm{N}$ may be due to its effect on plant carbohydrates metabolism which, led to better growth and dry matter accumulation. Also these results may be attributed to the excess of $\mathrm{N}$ stimulate absorption of water which increased fresh weight of plants (Milford and Watson, 1971). In this connection, Selim et al (2009) found that foliar application with urea significantly increased root length, root diameter, root fresh weight and sugar yield.

\section{Effect of micronutrients}

Foliar spray with $\mathrm{Zn}, \mathrm{Mn}$ and Fe individually or in mixture significantly affected root length and diameter as well as fresh weight of root and tops. Meantime, the increases were significant by using the mixture of $\mathrm{Zn}+\mathrm{Mn}+$ Fe followed by Fe alone in both seasons as compared with control (without micronutrients). The pronounced effect of micronutrients is mainly due to their effect on growth hormone production which has a direct effect on plant growth. These results are in agreement with those obtained by Soudi et al, (2008) who found that the mixture of $M n+Z n+F e$ has significantly increased all root and top growth parameters of sugar beet plants.

\section{Effect of interactions}

The interactions between $\mathrm{N}$ fertilizer rates and micronutrients affected positively but insignificantly all growth traits (Table 4).

\section{Root nutrients uptake:}

\section{Effect of $\mathbf{N}$ fertilizer rates:}

Application of $\mathrm{N}$ at the rate $60 \mathrm{~kg} \mathrm{~N} / \mathrm{fed}(75 \%$ of RR) significantly decreased $\mathrm{N}$ uptake (macronutrient) as well as $\mathrm{Mn}$ and $\mathrm{Zn}$ (micronutrients) but insignificantly decreased Fe (Table, 5). Contrary results, were obtained when sugar beet plants treated with $\mathrm{N}$ at $125 \%$ of $\mathrm{RR}$, Where it gave significant increase in $\mathrm{N}, \mathrm{Zn}$ and $\mathrm{Fe}$ in both seasons. Such effect may be duo to that $\mathrm{N}$ enhanced the uptake of other minerals, which finally was reflected as better growth. In this connection (Cai, and Ge, 2004) found that the nitrogen content of sugar beet plant was significantly and positively correlated with nitrogen amount used. 


\section{Table 4}




\section{Table 5}




\section{Effect of micronutrients}

Foliar application of micronutrients i.e. $\mathrm{Mn}, \mathrm{Zn}$ and Fe significantly increased their uptake and also $\mathrm{N}$ uptake. Data also found that spray with the mixture of $\mathrm{Mn}, \mathrm{Zn}$ and Fe was the best treatment where, it gave the highest values for $N, M n, Z n$ and Fe uptake.

\section{Effect of interactions}

The interactions between $\mathrm{N}$ rates and studied micronutrients gave significant increase for $\mathrm{N}$ uptake only. Treatment with $\mathrm{N}$ at the rate $125 \%$ of RR along with foliar spray with the mixture of $\mathrm{Zn}, \mathrm{Mn}$ and Fe gave the best values of $\mathrm{N}$ uptake than other interactions under study.

\section{REFERENCES}

1. O. A. C. 1990. "Official Methods of Analysis". Association of Official Analysis Chemists, 15 th Ed. Washington, USA.

2. Cai Baiyan and Ge Jingping. 2004. The Effect of Nitrogen Level on mMain Nutrient of sugar beet. Nature and Science, 2 (4) 79-83.

3. Franzen. 2003. Fertilizing sugarbeet North Dakota State University Fargo, North Dakota 58105.

4. Jozefyova Lucie, Josef Pulkrabek and Jaroslav Urban. 2004. Effect of harvest time on sugar beet fertilized with increased nitrogen. Food, Agriculture \& Environment Vol.2 (1): 232-237.

5. Milford, C. F. and D. J. Watson. 1971. The effect of nitrogen on the growth and sugar content of sugar beet. Ann. Bot. 35,287.

6. Selim, E. H. H., M.A. Abdou, H. M. Sarhan and I. H. Dalia. El. Geddawy. 2009. Effect of Foliar fertilization with urea and gibberellic acid on sugar beet (Beta vulgaris L) J. Agric. Sci. Mansoura Univ., 34(3). 1829- 1837.

7. Shalaby, S. A. 1998. The response of sugar beet to micro-nutrients as foliar application. Egypt J. Appli. Sci., 13:320-331.

8. Soudi, Amal K.M. and H. El-Guibali, Amal. 2008. Effect of foliar application with some micronutrients on yield and quality of sugar beet. J. Appl. Sci., 23(3):41-51.

9. Soudi, Amal K. M., Sama E. H. Omran and Kh. A. Aboushady. 2008. The response of sugar beet to nitrogen and phosphor mineral and partial biofertilization using some micronutrients foliar application. Egypt. J. Appl. Sci. 23 (4-B) 502-516.

10. Steel R. G. and H. H. Torrie. 1980. Principles and Procedures of statistic 2nd Ed. McGeaw-Hill, New York. 
11. Moustafa, Zeinab R. and. Samia E. H. Omran. 2006. Effect of Foliar Spray with Boron or Magnesium in Combination with Nitrogen Fertilization on Sugar Beet Plants.Egypt.j.soil sci.46(.2):115-129.

12. Moustafa, Zeinab R., H.W.A. Wahba and Samia H. Ashmawy. 2006. Effect of injected ammonia gas and applied potassium rates with or without some micronutrients on sugar beet productivity Annals Of Agric. Sc.,Moshtohor, Vol. 44(4): 1447-1460.

13. Zhou, J. C. 1993. The study on nitrogen nutrients of sugar beet. China. Beet 2:25-9.

14. Van Geijn, N. J., L. C. Giljam and L. H. De Nie. 1983. œ-amino nitrogen in sugar processing. In proceeding of the symposium (Nitrogen and Sugar Beet), international Institute for sugar beet research, Brussels, PP. 13-25.

15. Wettstein, D. 1957. Chlorophyll-lethal und der submikrostopiche formwechel der plastiden. Exptl. Cell Res., 12: 427-433. 


\section{تأثير التسميد النيتروجينى وبعض العناصر الصغرى على انتاجية وجودة بنجر السكر}

زينب رمضان مصطفي أمل محمد كامل سعودي خليل الثناوى محمد

قسم بحوث الفسيولوجي و الكبياء - معه بحوث الدحاصيل السكرية - مركز البحوث الزراعية

أقيمت تجربتان حقليتان فى موسمى 2009/2008 و 2010/2009 بمحطة بحوث سخا

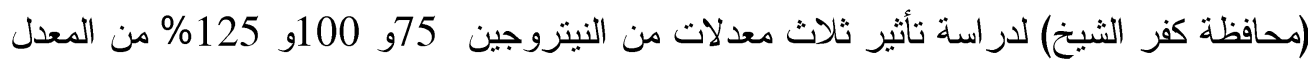

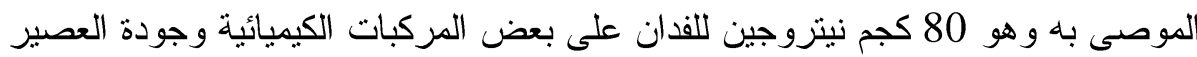

و المحصول فى نبات بنجر السكر الذى تم رشه بالعناصر الصغرى منل المنجنيز و الزنك و الحديد اما

مفرده او خليط بينهم.

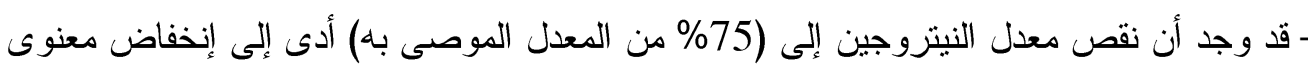

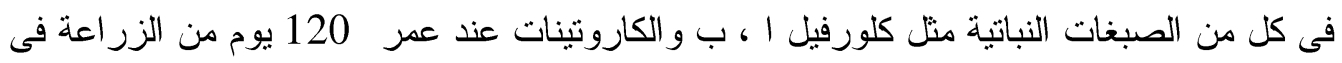
كلا الموسمين. وأيضا ادى إلى انخفاض معنوى لجوده العصبر مثل السكروز وبعض القياسات التكنولوجيه ( السكر المستخلص و السكر المفقود في المو لاس ومعامل السكر) وبعض صغود صفات

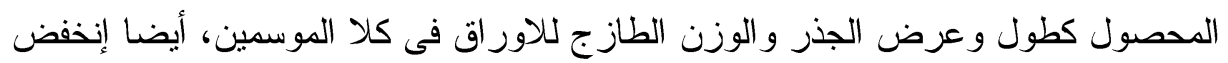

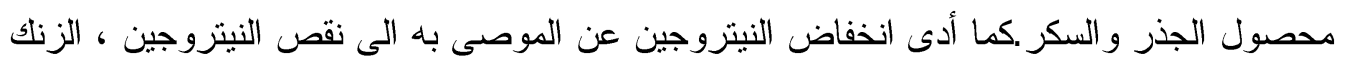

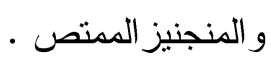
- من ناحية أخرى أدى ارتفاع التسميد النيتروجينى إلى 100 كجم نيتزوجين للفدان ( 125\% من

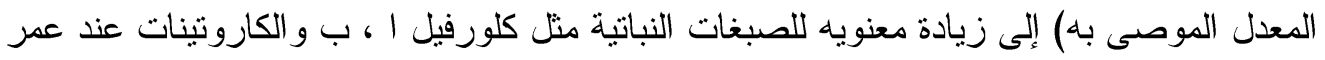

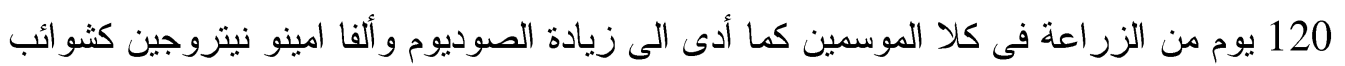

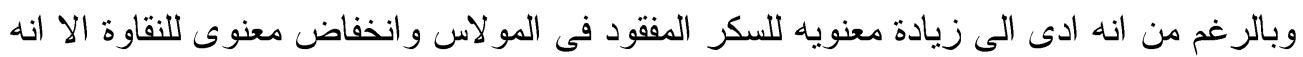

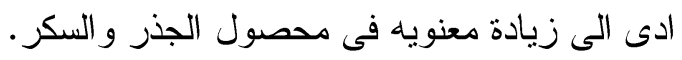

- أدى الرش الورقى بالعناصر الصغرى (المنجنيز، الزنك و الحديد) منفرده أو مجتمعه الى زيادة

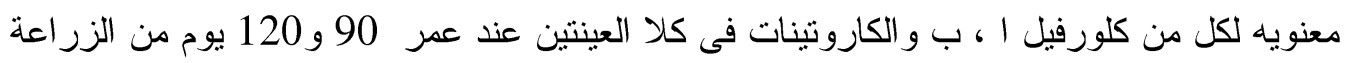
فى كلا الموسمين و أيضا الى زيادة السكروزو البوتاسيوم و ألفا امينو نيتروجين ولكنه خفض ملهن معنويا

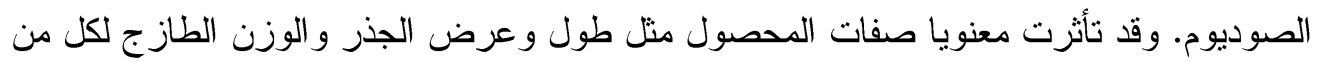
الجذر و المجموع الخضرى ، كما أدى الرش الورقى بالعناصر الصغرى الى زيادة معنويه لـحصول السكر (طن/فدان) وزيادة الممتص من النبتروجين ، الزنك ، المنجنيز و الحديد

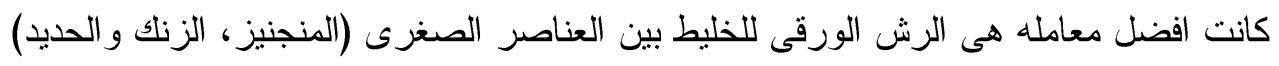

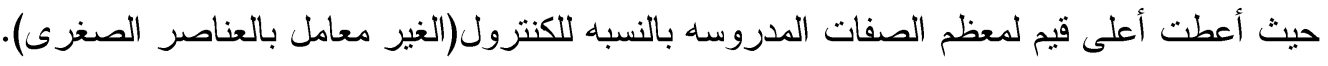

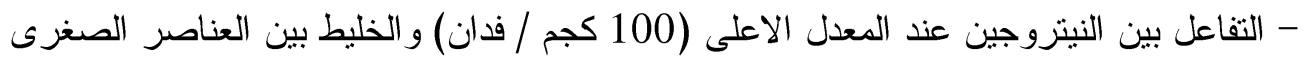

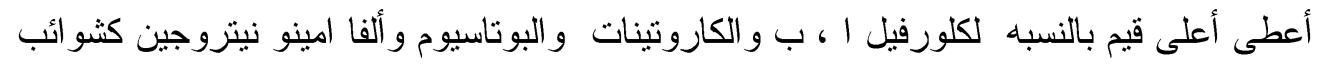
و أعلى نقاوة للعصبر و النيتزوجين الممتص. باله 